\title{
The Influence of MFN Clause on International Investment Dispute Settlement Procedure to Investor's Home Country
}

\author{
Hai Tian \\ Department of Law, Northwest University, Xi'an, China
}

Email address:

thwilliam@126.com

\section{To cite this article:}

Hai Tian. The Influence of MFN Clause on International Investment Dispute Settlement Procedure to Investor's Home Country. International Journal of Law and Society. Vol. 1, No. 1, 2018, pp. 10-15. doi: 10.11648/j.ijls.20180101.12

Received: October 30, 2017; Accepted: November 16, 2017; Published: December 24, 2017

\begin{abstract}
The purpose of the MFN clause in the International Investment Treaty is to promote the interests of the parties, not to derogate from their interests. From the perspective of the investor's home country, the MFN clause to expand the international arbitration practice applicable to the international investment dispute settlement procedure has the advantages and disadvantages of the investor's home country, and the overall situation is more harm than good. Which will seriously affects the investor's home country's own understanding of the obligations under the investment treaty, and thus inevitably affect the investor's home country on their own contract in the international law of the legitimacy of the judgments and expectations.
\end{abstract}

Keywords: MFN Clause, Investment Dispute Settlement, Investor Home Country

\section{Introduction}

Most-Favored-Nation Treatment refers to the treatment of a person or a person who has a relationship with the beneficiary or has a definite relationship with no less favorable than that accorded to a third country or to a person who has a relationship with the above the treatment of things. In international treaties, provisions on MFN are MFN clauses.

Traditionally, the scope of application of the most-favored-nation clause has been a substantive field, and there has been no international controversy, but the "Maffezini v. Spain case" accepted by the 1997 Washington Convention Arbitration Tribunal (ICSID) has become a turning point. In the case, Maffezini (Argentina), a foreign investor, argued that the MFN clause could be applied to the investment dispute settlement procedure and that it could invoke the provision to enjoy a more favorable treatment of the dispute settlement procedure given by the host country (Spain) to a third country. The arbitral tribunal considers that the most-favored-nation clause in a bilateral investment treaty can be applied to a dispute settlement procedure and that an investor may choose a more favorable dispute settlement provision under the MFN clause. $^{1}$

Under the demonstration and guidance of the "Maffezini v.

1 Maffezini v. Spain, ICSID Case No. ABR/97/7. Decision on Objection to Jurisdiction of January 25, 2000. para. 58.
Spain case", investors frequently tried to avoid the jurisdiction of the host country by invoking the most-favored-nation clause to the international arbitration tribunal for investment arbitration. Most of the most-favored-nation clauses are applied to the procedural matters of investment dispute settlement, which makes the application of the traditional MFN clause, which focuses on the protection of substantive rights, to the expansion of procedural rights.

This practice of the International Arbitration Tribunal has caused great controversy in the international community, reflecting the collision of different legal rights. This is because, in contracting practice, the host country, on the basis of various considerations, often provides for differentiated dispute settlement procedures in investment treaties contracted with different countries, which can be classified as host country local remedies and international Arbitration two mechanisms. In international investment treaties, these two mechanisms are generally mutually exclusive, choose a kind of can no longer choose another (such as the fork in the provisions of the restrictions). When the host government and foreign investors have investment disputes, the mechanism of resolving disputes becomes the focus of both sides.

The applicable dispute settlement mechanism is different and the outcome of the future referee may be quite different. So what is the difference between the parties at this time as a result of the local relief through the host country or through international arbitration? Thus, this divergence is in fact a 
direct conflict between the domestic jurisdiction of the host State and the international jurisdiction of international arbitration.

For the MFN clause can be applied to the international investment dispute settlement procedures, the current domestic and foreign scholars there is a huge controversy, the reasons for the parties to the dispute, regardless of which side did not form an overwhelming victory. ${ }^{2}$ In general, the current results are mainly from the perspective of legal interpretation of the study of the problem, based on the most favored nation clause in the wording of the statement itself, which is based on the real level of research. The author try to change the angle, with the perspective of legislation, from the point of view to talk about the views of the problem.

From the legal point of view, the host country and the investor's home country in the International Investment Treaty provisions of the most favored nation clause is intended to promote the interests of all Contracting Parties, rather than derogating from their interests. Most of the MFN provisions apply to the practice of international investment dispute settlement procedures clearly have a great influence on the judicial sovereignty of the host country, and the current research results are mainly concentrated, and the results of this practice will also have an impact on the investor's home country.

Therefore, the question raised in this paper is: What is the effect of applying the most-favored nation clause on the international investment dispute settlement procedure to the investor's home country? Is it in line with the legal expectations of the investor's home country contract?

\section{The Purpose of the Investor's Home Country to Conclude the MFN Clause}

\subsection{The Source of the MFN Treatment for Investors}

In accordance with the theory of international treaty law, international treaties are binding provisions between States and States that are established by international organizations to create legal rights and obligations between States Parties. That the signatories of international treaties must be the subject of international law, international treaty is the main meaning of the main body of international law. From the common expression of the MFN clause in the International Investment Treaty, the most-favored-nation beneficiaries are investors (investments) of the other Contracting States.

Since the signatories of the IIAs are the home country of the host country and the investor, the investor does not have the ability to conclude the international treaty, but now enjoy the MFN right in the international investment treaty, where is the investor's right I believe that can be understood from the

2 Zhu Mingxin: "The most-favored-nation treatment clause applies to the appearance and essence of the investment dispute settlement procedure - based on the perspective of treaty interpretation", "Law and business Studies", No. 3, 2015, p. 171. following two aspects:

First, the contract law theory, the parties through the consent of the contract can be set aside third than the right without the consent of the third person, that is, his contract. ${ }^{3}$ The State, as a party to an international treaty, is legally able to legally set the MFN status for an investor in an international treaty based on the principle of sovereign independence and its own meaning. In such a case, the host country and the investor's home country may form a written agreement without any agreement with the investor.

Second, from the transfer of legal rights, based on the expression of the MFN clause in an investment treaty, it can be seen as the transfer of the investor's right to the transfer of the most-favored-nation right in the treaty of investment between the home country and the host country The investors of the country, this transfer does not require investors to make meaning that. ${ }^{4}$

\subsection{The Interests of Investors Can Not Go Beyond the Parental Purpose}

In the case of jurisprudence, the application of the MFN clause does not prejudice the interests of the State party. This is because the contracting parties to the investment treaties are different countries, not private ones. The treaty stipulates that the most favored nation clause is intended to preserve the interests of the State party, even if the rights and protection are given to investors (investment) in the investment treaty, but for the ultimate purpose of the State party. Therefore, from the legal point of view, as the interests of investment treaty holders, investors enjoy the benefits can not go beyond its home country, in particular, investors can not choose to apply the terms of a treaty and damage the interests of their home country.

From the point of view of the distribution of benefits and risks, applying the MFN clause to the investment dispute settlement procedure will have the following effect on the investor's home country.

\section{Benefit to the Investor's Home Country: Help to Improve the Protection of Its Own Investors}

Although a large number of international investment agreements provide investors with domestic remedies (including administrative compensation and judicial remedies in host countries) and international arbitration, this provision makes virtually the only way to resolve international investment disputes. ${ }^{5}$ This is because:

First, the practice shows that in the vast majority of cases, investors out of instinct, the host government and the legal

\footnotetext{
3 Zheng Yubo: "Civil Law Debt Book", China University of Political Science and Law Press, 2004, pp. 358-359.

4 Shi Hui: "Criticism and Reconstruction of Investment Treaty Arbitration System", China Law Press, 2008, pp. 23-24.

5 Cai Congyan: "Commercialization of International Investment Arbitration and" Commercialization "," Modern Law Journal", No. 1, 2011, pp. 153-154
} 
system of lack of trust, and the international investment arbitration neutrality and enforcement effectiveness of expectations, which will choose international arbitration as the way to resolve the dispute.

Second, the rules set forth in the modern international investment treaties impose a mandatory obligation on the parties, and these rules can be enforced through the international arbitration dispute settlement mechanism. ${ }^{6}$ What is more attractive to investors is that the international arbitration mechanism is a powerful "tooth" that breaks through the traditional exhaustion of local relief requirements, allowing foreign investors to directly question the host country's behavior by the international arbitral tribunal, thus being relatively independent The international tribunal provides the guarantee that the host State can fulfill its international obligations.

It can be said, therefore, through international investment arbitration to solve the international investment dispute has developed into a field of international investment law to resolve a normal state of dispute. ${ }^{7}$ But from the current practice, whether the most-favored-nation clause in the dispute settlement in the application of such disputes only occurred in international arbitration. The investor's initial request for arbitration is not based on the MFN clause, but the host country's breach of the substantive obligation in the investment treaty, and the investor invites the MFN clause only to secure the establishment of the jurisdiction of the international tribunal, which is in conflict with the host country's violation of MFN The nature of the different. The use of MFN provisions for investment dispute settlement procedures gives investors the opportunity to "treaty selection" and "treaty collocation".

\subsection{Treaty Selection}

The so-called "treaty selection" refers to the choice of a third party treaty in the dispute settlement method to replace the basic treaty dispute settlement. For example, the investment treaty between the two countries stipulates the most-favored-nation clause, which does not provide for international arbitration in the dispute settlement procedure or only provides for the submission of a small number of disputes to international arbitration, but the provisions of the dispute settlement procedure in the investment treaties between the State and the State But the provisions of international arbitration or the provisions of a larger range of international arbitration, then the $\mathrm{B}$ investors may be required to apply the basic treaty in the most favored nation clause to claim the application of the B \& B investment treaty dispute settlement procedures.

\subsection{Treaty Collocation}

The so-called "treaty with" refers to the investors will be the

6 Keohane, R. O. \& A. Moravcsik \& A. M. Slaughter, Legalized Dispute Resolution: Interstate and Transnational, International Organization, 54 (3), 2000. p. 485.

7 UNCTAD, Latest Development in Investor-State dispute settlement, IIA Monitor, No 1, New York and Geneva: United Nations, 2009. pp. 45-48. basis of the treaty and third-party dispute settlement procedures in the "mixed with" to avoid the two parts of the treaty against their own, and leave their own part. For example, investors require the adoption of the most-favored-nation clause to select the applicable host country to sign all of the investment treaties for their "more favorable" part, select a favorable dispute from the A treaty, select a favorable arbitration institution in the B treaty, Favorable rules of proof.

From the practice of current international arbitration, the fact that the most favored nation clause can be applied to dispute settlement procedures is increasing. The fact that investors wish to use the most-favored-nation clause "selection" or "collocation" for the basis of the underlying treaty on which the investment is based On the more favorable third-party treaties of the dispute settlement provisions, so as to enjoy the latter in the dispute settlement provisions of the more favorable treatment. Of course, investors need to carefully study the host country and its home country signed the investment treaty in the most favored nation terms and content of the dispute resolution clause, which is the necessary preparatory work for investment. ${ }^{8}$

In the case of the home country of the investor, if the domestic investor "chooses" or "matches" the more favorable dispute settlement procedure through its MFN clause in its investment treaty, it is possible to avoid discrimination in the event of unfair dispute settlement procedures in the host country. This is undoubtedly in line with the expectations of the home country for the application of the MFN clause in the underlying treaty.

\section{The Home Country's Disadvantages: Can Not Appeal to Investors "Filter"}

The host country and the investor's home country are the contracting parties of the investment treaty and are eligible to choose the interests of the treaty. Investors can not override the will of the State party, especially the home country.

The international investment dispute settlement procedure stipulated in the current international investment treaty, its particularity lies in the particularity of the identity of both parties. If the dispute settlement under the international trade treaty is mainly based on the "state-state" model, the dispute under the international investment treaty arises under the "investor-host country" model. In these two different models, the control of the dispute settlement procedure is different for States Parties (including the home country of the investor).

\section{1. "State - State" Model}

In the "State-State" model (typically represented by the GATT / WTO), the State party has a strong control over the dispute settlement process. This is manifested in:

First, the autonomy of the will of the state. The State party

8 Huang Shixi: "Application of MFN Clauses in International Investment Arbitration and New Development of Jurisdiction", Journal of Legal Science, Vol. 2, 2013, p. 812. 
may, according to its own wishes, decide whether to submit the dispute to the dispute settlement mechanism in the trade treaty; it may decide according to its own intention to decide what kind of dispute settlement procedure to resort to; and, in accordance with its own wishes, Decide whether to change or give up their claims; can be in the dispute after winning or lost according to their own wishes to decide whether to fulfill the ruling. In sum, in this model, the will of the State party is extremely important and autonomous. Even the international organizations that have a highly effective dispute resolution mechanism (DSU) in the WTO, also pay great attention to the will of the members, such as the DSU Article 23, although the dispute settlement agency's exclusive jurisdiction of the dispute, but in the DSU Article 4 The consultation will provide for the necessary procedures for the submission to the panel of experts, and for 60 days during the consultations, in particular, "even if it has been 60 days, the disputing party is still in a position to consult."

Second, the private sector of the State party generally does not have the opportunity to resolve trade disputes on an equal footing with the other country, and can only request the home country to initiate dispute settlement procedures between countries, such as the WTO dispute settlement mechanism or the dispute settlement mechanism in regional trade agreements Settle the dispute. At this time, the mother country can reject the private request, but also for its claim of the right, but to their own private request to "filter", excluding those who can not even agree with their home country's request, making the private will and motherland will be unified.

\section{2. "Investor - Host Country" Model}

In the "investor-host country" model, the emergence of international arbitration has deprived the State party of the control of the dispute settlement procedure. If the host country and the investor's home country do not agree on international arbitration in the investment treaty, or agree on a very small international arbitration, or if the precondition is attached to the international arbitration, once the investor applies the MFN clause to the third party treaty, Better "international arbitration mechanism or arbitration conditions, at this time the investor's home country can not be the investor's request to "filter". Resulting in the fact that the investor may, without the consent of his home country, send the host country directly to the international tribunal or to make a legal request that does not necessarily agree with his home country. ${ }^{9}$ For example, in the Mondev International Ltd v. United States of America case, the investor's home country, Canada, submits to the arbitral tribunal that the investor's claim should be dismissed physically. ${ }^{10}$ At this point the private meaning constitutes the coercion of the meaning of the two countries. Especially investors, this "no motherland" approach is likely to seriously

9 Chen An, Cai Congyan: "New Development of International Investment Law and New Practice of China's Bilateral Investment Treaty", Fudan University Press, 2007, p. 209.

10 Mondev International Ltd. v. United States of America, Award, http://www.state.gov/s/l/c3758.htm, last visited May. 18, 2017. affect the interests of the home country and the host country. ${ }^{11}$

\section{A Comparison of the Pros and Cons of the Investor's Home Country}

Therefore, the MFN clause applies to the investment dispute settlement procedure in terms of the pros and cons of the investor's home country. For the following reasons, this applies to the investor's home more harm than good.

\subsection{Purpose of the Contract}

States Parties often provide different dispute settlement procedures in different investment treaties for a specific purpose. For example, some of the treaties provide for international arbitration, some of which only provide Contracting States' remedy; some investment treaties provide for a larger scope of arbitration, some of which prescribes a smaller scope of arbitration. This shows the difference in dispute settlement procedures in different investment treaties. This difference is perceived by some scholars as "different contractual negotiations that produce different treaty provisions, rather than host country's country discrimination." ${ }^{12}$ Even some international tribunals think that "the dispute settlement clause in each specific investment treaty is achieved through long-term negotiations between the two governments and can not judge the existence of discrimination, and it is not casually assumed that they agree that these terms are expand." 13

That being the case, why should the State party introduce the most-favored-nation clause at the beginning of the contract with the International Investment Treaty and at the same time unclear its relationship with the dispute settlement procedure? It is difficult for the author to find the relevant negotiating information or convincing evidence to illustrate the problem. It was argued that contractual negotiations in any country could not be limited and unobtrusive, limited by professional levels and contracting capacity, and that negotiators of investment treaties could not be expected to think like legal experts. ${ }^{14}$ He conclusion of an international treaty is a product of a benefit game between the parties and is achieved in the process of conflict of interest and coordination among the parties. Under normal circumstances, the acceptance of certain provisions by the Parties is not very satisfactory. The negotiators of the two sides often resort to vague wording to some of the controversial issues in order to reach an agreement as soon as possible. Skill, nothing wrong. In addition, the negotiation of the contract is not only the participation of a

11 Susan D. Franck, The Legitimacy Crisis in investment Arbitration: Privatizing Public International Law Through Inconsistent Decision, Fordham Law Review, Vol. 73, 2005. p. 1525 .

12 Liang Danni: A Study on the Application of the Most Interested Necessary Terms of the International Investment Treaty - An Analysis Based on Iraqi Lan Company v. China, "Journal of Legal Studies", Vol. 2, 2012, p. 101.

13 Plama Consortium Limited v. Republic of Bulgaria, Decision on Jurisdiction. para. 207.

14 Weng Xiantao: "China Investment Protection Agreement Model (Draft) on the draft (1)", "International Journal of Economic Law," No. 4, 2011, p. 195. 
professional lawyer, and the term of the treaty is not fully reviewed from the legal point of view, so the text of the treaty becomes the "lain-fact view". ${ }^{15}$ Perhaps it is for this reason that only in practice triggered the MFN clause can be applied to the dispute settlement dispute settlement process.

However, no matter how the interests of the State party are negotiated, it is certain that, in general, the issues raised by the State party in the negotiations are often closely related to their own interests. The introduction of the most-favored-nation clause and the terms of the dispute settlement procedure in the investment treaty are the starting point for the benefit of the State party in the future, and the hope that the two categories of articles will be "peaceful coexistence": on the one hand, the benefits of multilateralization of MFN, While differentiated settlement of investment disputes.

If you disregard this difference and apply the most-favored-nation clause, it is tantamount to requiring investors to choose "favorable interests" in the selection of favorable dispute settlement arrangements. Which would lead to confusion in the investment dispute settlement process and impede the normal and healthy development of international trade, leading to the failure of the contracting parties to the State party. It may not be long before the countries concerned will consider withdrawing the MFN clause or the "investor-host country" international arbitration dispute settlement solution in the investment treaty. This will have a negative impact on the prosperity and promotion of international investment. In particular, will seriously affect the enthusiasm and confidence of the State party in the most-favored-nation clause, which is disastrous for the development of MFN clauses. Perhaps it is with such a concern, there are some investment agreements or free trade agreements will no longer require the most favored nation clause. For example, Jordan and Singapore and May 2004 signed a free trade agreement does not contain MFN terms, Albania in 2004 and Romania and Serbia and Montenegro signed a free trade agreement and no MFN clause. Therefore, applying the MFN clause to the investment dispute settlement procedure may result in the failure of the parent country's contract.

\subsection{Role Conversion}

From the point of view of legal application, international arbitration is introduced as an investment treaty as a dispute settlement, which is equivalent to the change of domestic law that traditionally local remedies belonging to the host country into the choice of domestic law and international law. ${ }^{16}$ Compared with the domestic law regulation, international law has restricted the domestic law, that is, the regulation of international law has more obvious "re-regulation". This will have a significant impact on the judicial sovereignty of the host country.

15 Chen Xin: "Legal Interpretation of WTO Dispute Settlement - Judicial Restraintism and Judicial Activism", Peking University Press, 2010, p. 1.

16 Denise Manning Cabral, The Imminent Death of the Calvo Clause and the Rebirth of the Calvo Principle: Equality of Foreign and national Investors, Law and Policy in International Business, Vol. 26, 1995. p. 1198-1199.
So Yannick Radi think the most favored nation clause in the investment treaty is the "Trojan horse" set up by both parties and is the "Trojan horse": whether the MFN clause applies to the investment dispute settlement procedure or "taming the Trojan horse": refusing to apply the most-favored nation clause to the investment dispute settlement procedure, Which leaves the full policy space of the State party. ${ }^{17}$ It should be said that "policy space" is a very broad concept that can include political, economic, military, public order and other dimensions. The author argues that the application of the MFN clause to the investment dispute settlement procedure depends on the role of the State party in international investment, from the point of view of the interests of the State party.

If the State party is in the role of a capital-exporting country, it tends to apply the most-favored-nation clause to the investment dispute settlement procedure from the point of view of expanding investment and protecting its own investor. On the other hand, if the State party is in the role of a capitalist, it tends to apply the most-favored-nation clause to the investment dispute settlement procedure from the point of view of its own regulatory power and the maintenance of its national security. In recent years, in the field of international investment, with the resurrection of Calvoism in Latin American countries, some countries have adopted a conservative attitude towards MFN clauses and investment dispute settlement procedures, in the final analysis, inseparable from the role of these countries as capital-importing countries. But the question is that, as the economic situation changes, once the role of the country has changed, such as from the exporting country to the importing country, or the emergence of the role of the same, both the exporting country and the importing country, then this time again How to judge "policy space"?

As a result of the multilateralization effect of MFN clauses, once the most-favored-nation clause is suitable for investment dispute settlement procedures, the originally differentiated dispute settlement procedures will be "multilateralized". This allows foreign investors to sue the host country directly to transnational tribunals (arbitral tribunals) without requiring general international law, such as "exhaustion of local remedies," to require the dispute to be referred to the domestic courts of the State party. This practice undoubtedly limits the national sovereignty of States parties. ${ }^{18}$

Although the MFN clause applies to investment dispute settlement procedures as a home country for investors, it is not excluded from the protection of domestic investors in the case. But once the two countries in the future role of exchange or mixed, the home country's situation will be very embarrassing, and even suffer, more harm than good. For example, the United States has been advocating the so-called "high

17 Yannick Radi, The Application of the Most-Favored-Nation Clause to the Dispute Settlement Provisions of Bilateral Investment Treaties: Domesticating the "Trojan Horse", The European Journal of International Law, 2007, Vol. 18 No. 4. p. 11.

18 Schneiderman, D, Globalisation, Governance, and Investment Rules, in J. Glarke \& G. R. Edwards, Global Governance in the Twenty-first Century, Houndmills, Basingstoke, Hampshire: Palgrave Macmillan, 2004. p. 68. 
standard" investment rules in the world, especially the international arbitration mechanism. However, with the repeated experience of the North American Trade Agreement (NAFAT), it has begun to reflect on the shortcomings of international arbitration and has put forward reforms such as the establishment of an appeal mechanism and the exclusion of MFN provisions on the application of investment dispute settlement procedures.

\section{Conclusion}

The application of the MFN clause to the investment dispute settlement process will seriously affect the accurate understanding of the home country's obligations under the investment treaty and thus necessarily affect the judgment and expectation of the home country's legitimacy of its contracting acts in international law. Thus, unless the State party is expressly in the treaty, the scope of application of the MFN clause does not include an investment dispute settlement procedure.

\section{References}

[1] Maffezini v. Spain, ICSID Case No. ABR/97/7. Decision on Objection to Jurisdiction of January 25, 2000. para. 58.

[2] Zhu Mingxin: "The most-favored-nation treatment clause applies to the appearance and essence of the investment dispute settlement procedure - based on the perspective of treaty interpretation", "Law and business Studies", No. 3, 2015, p. 171.

[3] Zheng Yubo: "Civil Law Debt Book", China University of Political Science and Law Press, 2004, pp. 358-359.

[4] Shi Hui: "Criticism and Reconstruction of Investment Treaty Arbitration System", China Law Press, 2008, pp. 23-24.

[5] Cai Congyan: "Commercialization of International Investment Arbitration and" Commercialization", "Modern Law Journal", No. 1, 2011, pp. 153-154.

[6] Keohane, R. O. \& A. Moravcsik \& A. M. Slaughter, Legalized Dispute Resolution: Interstate and Transnational, International Organization, 54 (3), 2000. p. 485.
[7] UNCTAD, Latest Development in Investor-State dispute settlement, IIA Monitor, No 1, New York and Geneva: United Nations, 2009. pp. 45-48.

[8] Huang Shixi: "Application of MFN Clauses in International Investment Arbitration and New Development of Jurisdiction", Journal of Legal Science, Vol. 2, 2013, p. 812.

[9] Chen An, Cai Congyan: "New Development of International Investment Law and New Practice of China's Bilateral Investment Treaty", Fudan University Press, 2007, p. 209.

[10] Mondev International Ltd. v. United States of America, Award, http://www.state.gov/s/l/c3758.htm, last visited May. 18, 2017.

[11] Susan D. Franck, The Legitimacy Crisis in investment Arbitration: Privatizing Public International Law Through Inconsistent Decision, Fordham Law Review, Vol. 73, 2005. p. 1525.

[12] Liang Danni: A Study on the Application of the Most Interested Necessary Terms of the International Investment Treaty - An Analysis Based on Iraqi Lan Company v. China, "Journal of Legal Studies", Vol. 2, 2012, p. 101.

[13] Plama Consortium Limited v. Republic of Bulgaria, Decision on Jurisdiction. para. 207.

[14] Weng Xiantao: "China Investment Protection Agreement Model (Draft) on the draft (1)", "International Journal of Economic Law," No. 4, 2011, p. 195.

[15] Chen Xin: "Legal Interpretation of WTO Dispute Settlement Judicial Restraintism and Judicial Activism", Peking University Press, 2010, p. 1.

[16] Denise Manning Cabral, The Imminent Death of the Calvo Clause and the Rebirth of the Calvo Principle: Equality of Foreign and national Investors, Law and Policy in International Business, Vol. 26, 1995. p. 1198-1199.

[17] Yannick Radi, the Application of the Most-Favored-Nation Clause to the Dispute Settlement Provisions of Bilateral Investment Treaties: Domesticating the "Trojan Horse", The European Journal of International Law, 2007, Vol. 18 No. 4. p. 11

[18] Schneiderman, D, Globalisation, Governance, and Investment Rules, in J. Glarke \& G. R. Edwards, Global Governance in the Twenty-first Century, Houndmills, Basingstoke, Hampshire: Palgrave Macmillan, 2004. p. 68. 